\title{
Development of Implementation Guidlines for Maintenance, Repairation and Determine Material Spesifications for Mechanical Component Design in Government Own Green Building Based On Work Breakdown Structure
}

\author{
Dwi Endah Aryaningrum, Yusuf Latief, Leni Sagita Riantini, Budi Susilo \\ Department of Civil Engineering, University of Indonesia, Jakarta Indonesia
}

\begin{abstract}
The development of green buildings has become a global issue as global climate change is gradually becoming a serious concern for the future. Government buildings can be categorized as buildings that must comply with green building requirements, because they consume energy, water and other resources with large quantities. The absence of guidelines in maintenance and repair of government buildings will have an impact on the security and comfort of building users. In addition, the absence of guidance regarding the material specifications used will also result in a material stock system for maintenance and repair being ineffective. This study discusses the development of implementation guidelines for maintenance, reparation and determine material specifications for mechanical components design in government own green buildings based on work breakdown structure. This research will detail starting from the sub work section, work package, alternative design, implementation requirements, activities, resources and material specifications. With the implementation guidelines for maintenance, reparation and determine material specifications for mechanical components design in government own green buildings based on work breakdown structure (WBS) expected maintenance and reparation of government buildings can be implemented maximally, according to specifications and functions.
\end{abstract}

\section{Introduction}

The main purpose of green building developement is to create a healthy environment based on resource use and efficient ecological design [1]. In Singapore, a building is considered green if it meets the requirements under the Green Mark Scheme, which adopts assessment criteria that include energy efficiency, water efficiency, environmental protection, indoor environmental quality, features and other green innovations [2]. In Indonesia, matters concerning green building are regulated in Peraturan Menteri Pekerjaan Umum dan Perumahan Rakyat Republik Indonesia No. 02 / PRT / M / 2015. Based on the regulation, government buildings can be categorized as buildings that must comply with green building requirements.

One component in a building that can support the concept of green building is a mechanical component. Mechanical work is a work that includes mechanical things, which essentially require a mechanical principle in its application. Mechanical systems applied in the building for the purpose of supporting activities carried out in the building, including in terms of comfort and security for each activity and the culprit in the building.
Mechanical problems that often arise in government buildings such as elevator damage, pipeline leakage and ineffective material stock systems for maintenance and reparation. This problem is caused by the absence of work implementation guidelines that explain the rules, standards used, material specifications and implementation requirements for maintenance and reparation of mechanical components.

Preparation of guidelines for maintenance and reparation of mechanical components refering to Peraturan Menteri Pekerjaan Umum No. 24 / PRT / M / 2008 will be developed structurally in the form of Work Breakdown Structure (WBS) as well as the need for material specifications for the design of mechanical components referring to green buildings.

With the implementation guidelines for maintenance, reparation and determine material specifications for mechanical components design in government own green buildings based on work breakdown structure (WBS) expected maintenance and repair of government buildings can be implemented maximally, according to specifications and functions.

\section{Research objectives}


The objectives of this research are :

1. Identify the sub work section and work package of maintenance and reparation mechanical components.

2. Identify alternative designs/methods, activities, implementation requirements and resources based on the sub work sectio and work package of maintenance and reparation mechanical components.

3. Identify material specifications for each resource on maintenance and reparation mechanical components.

4. Establish implementation guidelines for maintenance, reparation and specification of materials for mechanical component design in government own green buildings based on work breakdown structure.

\section{Literature review}

\subsection{Green building at government building}

According to Green Building Council Indonesia (GBCI), the concept of green building is planning, development, operation and maintenance that pay attention aspects in protecting, saving, reducing the use of natural resources, maintaining the good quality of the building and the air quality in in the room and pay attention to the health of its inhabitants who are all based on the principle of sustainable development. This study refers to the GBCI benchmark for existing building [3].

State buildings are buildings for official purposes that are state / regional property and held with financing sources derived from APBN, and / or APBD funds or other acquisitions (Article 1 point 1) [4].

\subsection{Work breakdown structure}

The WBS is a hierarchical decomposition of the total scope of work to be carried out by the project team to accomplish the project objectives and create the required deliverables. The WBS organizes and defines the total scope of the project and represents the work specified in the current approved project scope statement [5].

\section{Maintenance and Repair Work}

The scope of maintenance work includes the type of cleaning, weaning, inspection, testing, repair and / or replacement of building materials and equipment and other similar activities under the guidance of operation and maintenance of buildings [6].

The scope of building maintenance work includes the repair and / or replacement of building parts, components, building materials, and / or infrastructure and facilities based on document of technical plan of building construction, taking into consideration the document of construction implementation [6].

\section{Methodology}

To answer the research objectives, this research is using descriptive research with qualitative approach. Archive analysis and literature study are the methods used in data collection. Expert interview are conducted to validate the data. The sequence of the research can be examined in Figure 1. The Research Flow.

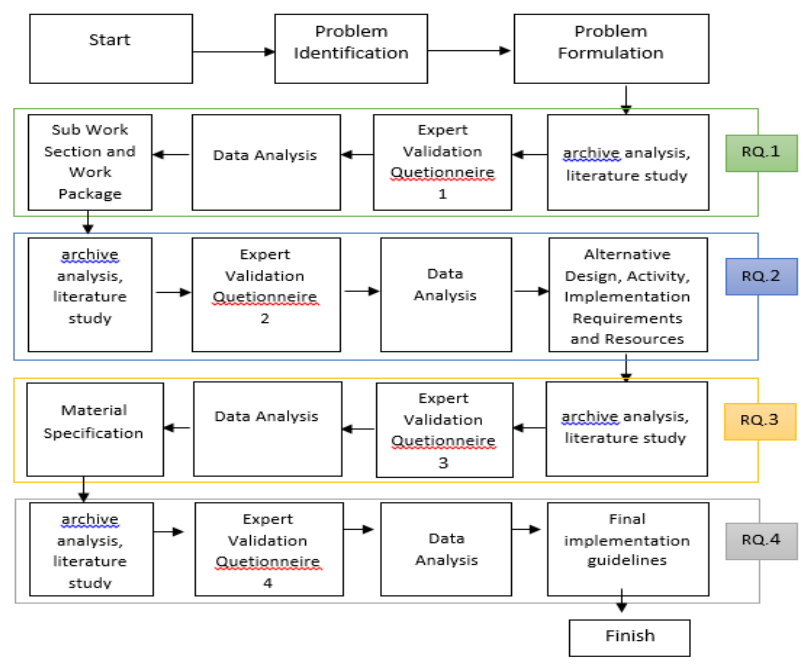

Fig. 1. The research flow.

\section{Result and discussion}

The results of this study are as follows :

1. To answer RQ.1 identify sub work section and work package of maintenance and reparation mechanical components for government own green building in Figure 2. Work Breakdown Structure (WBS) Diagram.

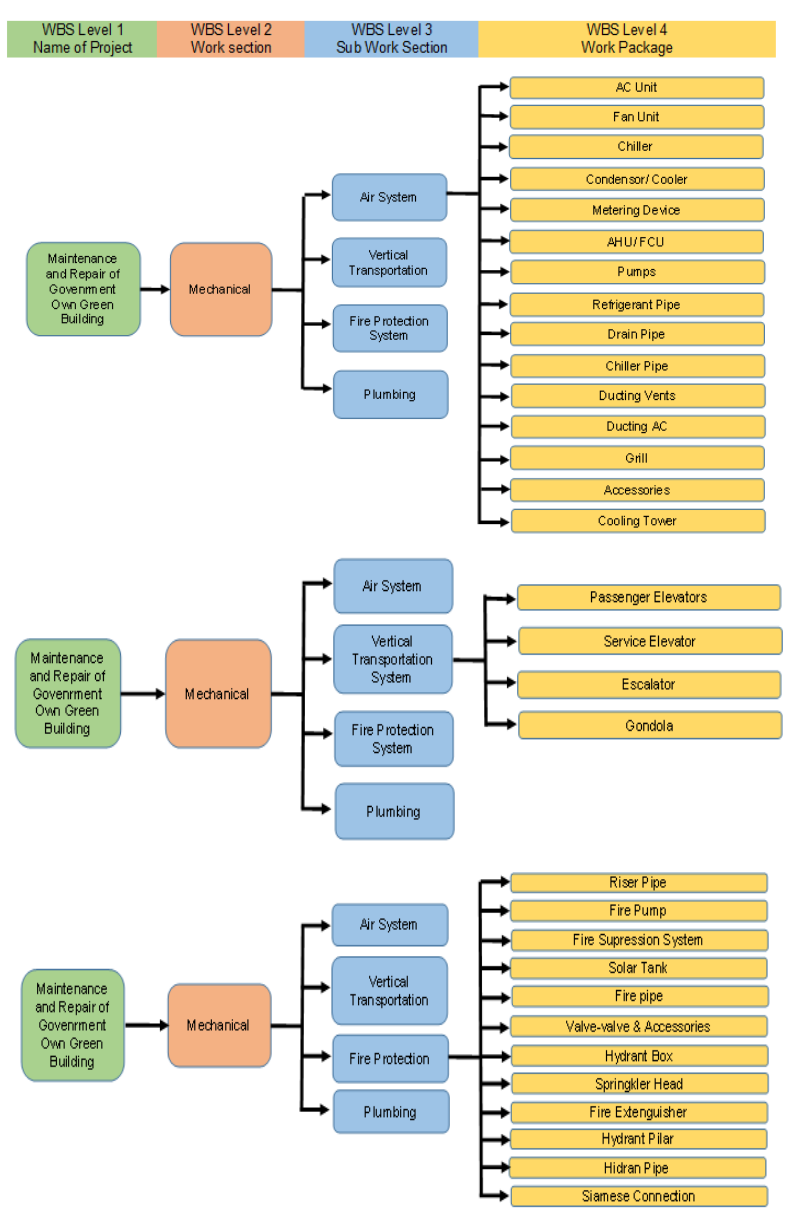




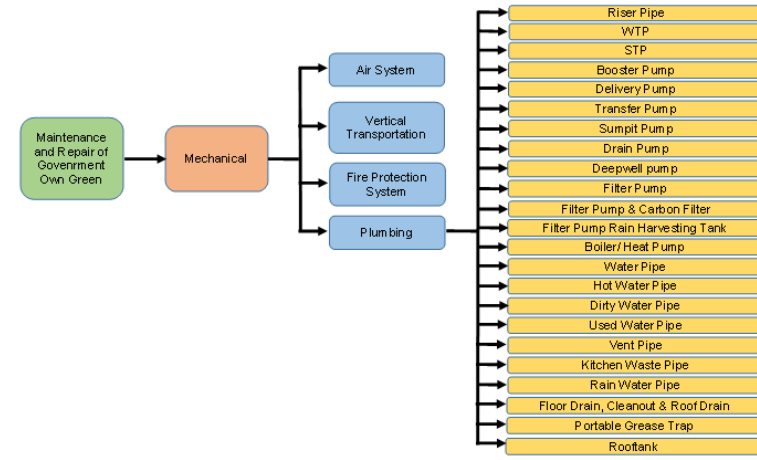

Fig. 2. Work breakdown structure (WBS) diagram.

Level 1 is for the name of project, maintenance and reparation of government own green building. Level 2 is work section, Mekanikal. Level 3 is for sub work section, air system, vertical transportation, fire protection system, and plumbing. Level 4 is work package.

2. To answer RQ.2 there is alternative designs/methods, activities, implementation requirements and resources based on sub work section and work package of maintenance and reparation mechanical components for government own green building. In table 1. shown alternative design/ method and activities of chiller as a sample in this study.

Table 1. Alternative design/ methode and activities of chiller

\begin{tabular}{|c|c|c|c|}
\hline $\begin{array}{c}\text { WBS Level } \\
3 \\
\text { Sub Work } \\
\text { Section }\end{array}$ & $\begin{array}{c}\text { WBS Level } \\
4 \\
\text { Work } \\
\text { Package }\end{array}$ & $\begin{array}{l}\text { Alternative } \\
\text { Design/ } \\
\text { Method }\end{array}$ & $\begin{array}{c}\text { WBS Level } 5 \\
\text { Activities }\end{array}$ \\
\hline \multirow[t]{8}{*}{ Air Sistem } & \multirow[t]{8}{*}{ Chiller } & \multirow{4}{*}{$\begin{array}{l}\text { Water Cooled } \\
\text { Chiller }\end{array}$} & Inspection \\
\hline & & & Maintenance \\
\hline & & & Repair \\
\hline & & & Testing \\
\hline & & \multirow{4}{*}{$\begin{array}{l}\text { Air } \quad \text { Cooled } \\
\text { Chiller }\end{array}$} & Inspection \\
\hline & & & Maintenance \\
\hline & & & Repair \\
\hline & & & Testing \\
\hline
\end{tabular}

From the table above shows that alternative design/ method of work package chiller are water cooled chiller and air cooled chiller. Level 5 is activity, which consists of inspection, maintenance, reparation and testing.

In mechanical work section, data collection from archive analysis and literature study obtained 96 alternative design/ method based on work package at Level 4. Expert validation results, obtained 83 alternative design / method corresponding to the work package of maintenance and reparation mechanical components for government own green building.

Each activity based on alternative design/ method will be details with implementation requirement and resources.

Table 2. Implementation requirement and resources of air cooled chiller

\begin{tabular}{|ll|}
\hline WBS Level 2 (Work Section) & : Mechanical \\
WBS Level 3 (Sub Work Section) & :Air System \\
WBS Level 4 (Work Package) & : Chiller \\
Alternative Design/ Method & : Air Cooled Chiller \\
\hline
\end{tabular}

\begin{tabular}{|c|c|c|}
\hline $\begin{array}{c}\text { WBS Level } 5 \\
\text { (Activity) }\end{array}$ & Requirement & $\begin{array}{c}\text { WBS Level } 6 \\
\text { (Resources) }\end{array}$ \\
\hline Inspection & $\begin{array}{l}\text {-Chiller check periodically. } \\
\text {-Compression check of the } \\
\text { compressor that measured at the } \\
\text { high pressure side (discharge) and } \\
\text { the low pressure side (suction). } \\
\text {-By using pressure gauge, oil } \\
\text { pressure as the lubricat parts } \\
\text { moving in the compressor are } \\
\text { measured periodically. While lhe } \\
\text { level of oil that can be seen in sigh } \\
\text { glass visually should be considered } \\
\text { and should not bel lower than } \\
\text { factory required. } \\
\text {-Check the refrigerant pressure on } \\
\text { the condenser and cooler on a } \\
\text { regular basis to determine whether } \\
\text { heat transfer is good or not. } \\
\text {-Check the fan motor that serves to } \\
\text { move the cooling air (especially for } \\
\text { condenser). } \\
\text { - routine checking of metering } \\
\text { device. } \\
\text { - inspection of water inlet and outlet } \\
\text { against leakage. } \\
\text {-Colling coil check against leakage } \\
\text { and corrosion. } \\
\text {--Check operation of the actuator } \\
\text { control zone. } \\
\text {-Inspection of the water damper } \\
\text { operation. } \\
\text {-Inspection of fresh air damper } \\
\text { operation. } \\
\text {-filter check. } \\
\text {-inspection of refrigerant, to use } \\
\text { non-CFC refrigerant. } \\
\text {-analyze whether } \\
\text { maintenance/ reparation } \\
\text { necessary. }\end{array}$ & $\begin{array}{l}\text { Man : } \\
\text {-Mechanical } \\
\text { Technician } \\
\text { Equipment : } \\
\text {-Checklist } \\
\text {-pressure } \\
\text { gauge }\end{array}$ \\
\hline Maintenance & $\begin{array}{l}\text { - Prepare the equipment and mateials } \\
\text { needed for chiller maintenance. } \\
\text { - Reset the metering device when the } \\
\text { refrigerant flow is interrupted. } \\
\text { - Clean the dirt on the compressor } \\
\text { valve and reset. } \\
\text { - add compressor oil periodically } \\
\text { - The condenser machine needs to be } \\
\text { cleaned regularly on the cooling } \\
\text { fluid side. The air-cooled } \\
\text { condenser requires cleaning of the } \\
\text { fins on the air side. } \\
\text { - For air-cooled condensers, external } \\
\text { airflow needs to be maintained } \\
\text { sufficiently and unobstructed, and } \\
\text { there is no short circuit between the } \\
\text { airflow out of the condenser and } \\
\text { the air flow to enter the condenser. } \\
\text { - Clean the surface of cooling coil. } \\
\text { - clean the actuator control zone. } \\
\text { - lubricate the air damper bearing. } \\
\text { - lubricate the fresh air damper } \\
\text { bearing. } \\
\text { - adding / replacing a non-CFC } \\
\text { refrigerant that has a small Ozone } \\
\text { Depleting Potential (ODP) value } \\
\text { (ODP <1). }\end{array}$ & $\begin{array}{l}\text { Man : } \\
\text {-Mechanical } \\
\text { Technician } \\
\text { Equipment : } \\
\text {-plastic/brass } \\
\text { brush } \\
\text {-water pump } \\
\text {-wipes } \\
\text { Material : } \\
\text {-chemical } \\
\text { liquid } \\
\text {-refrigerant } \\
\text {-oil }\end{array}$ \\
\hline Reparation & $\begin{array}{l}\text { - Prepare equipment and materials } \\
\text { needed for chiller repair. } \\
\text { - Damaged filters must be replaced } \\
\text { in order to function properly. } \\
\text { - Worn and rusty compressors that } \\
\text { cause leaks should be replaced. } \\
\text { - An unworkable condenser should } \\
\text { be replaced. } \\
\text { - Metering device that is not working } \\
\text { must be replaced. } \\
\text { - Evaporators that are not working } \\
\text { should be replaced. }\end{array}$ & $\begin{array}{l}\text { Man : } \\
\text {-Mechanical } \\
\text { Technician } \\
\text { Equipment : } \\
\text {-chiller set } \\
\text { repair } \\
\text { equipment } \\
\text { Material : } \\
\text {-filters } \\
\text {-compressors } \\
\text {-condensers } \\
\text {-metering }\end{array}$ \\
\hline
\end{tabular}




\begin{tabular}{|c|c|c|}
\hline & & $\begin{array}{l}\text { devices } \\
\text {-evaporators }\end{array}$ \\
\hline Testing & $\begin{array}{l}\text { - Prepare equipment and materials } \\
\text { needed for chiller testing. } \\
\text { - Periodically, recommissioning or } \\
\text { retro commissioning with } \\
\text { performance improvement targets } \\
\text { (KW / TR) on chiller equipment at } \\
\text { maximum } 3 \text { years with minimum } \\
\text { efficiency for water cooled chiller } \\
\text { (recip / screw chiller) is } 1.27\end{array}$ & $\begin{array}{l}\text { Man : } \\
\text {-Mechanical } \\
\text { Technician } \\
\text { Equipment : } \\
\text {-chiller set } \\
\text { testing } \\
\text { equipment }\end{array}$ \\
\hline
\end{tabular}

3. To answer RQ.3 Identify material specifications for each resource on maintenance and reparation mechanical components for government own green building. In table 3. shown material specification for air cooled chiller.

Table 3. Material specification for air cooled chiller

\begin{tabular}{|c|l|}
\hline $\begin{array}{c}\text { Alternative Design/ } \\
\text { Method }\end{array}$ & \multicolumn{1}{c|}{ Material Specification } \\
\hline Air Cooled Chiller & $\begin{array}{l}\text { 1. Refer to Standar Nasional Indonesia } \\
\text { (SNI) 6390:2011 [7]. }\end{array}$ \\
& $\begin{array}{l}\text { 2. Certified by ISO 14001 about } \\
\text { environmental management system. }\end{array}$ \\
& $\begin{array}{l}\text { 3. Certified by ISO 9001 about quality } \\
\text { management system }\end{array}$ \\
& $\begin{array}{l}\text { 4. Use non-CFC/ non-HCFC refrigerant } \\
\text { (ODP=0). }\end{array}$ \\
& 5. Regional Production. \\
\hline
\end{tabular}

Material specifications are determined to regulate material use, so that material stock systems become more effective. Material specification that use In this case, material specification that use in air cooler chiller are refer to Standar Nasional Indonesia (SNI) 6390-2011. It also must certified by ISO 14001 and ISO 9001, use non$\mathrm{CFC} /$ non-HCFC refrigerant $(\mathrm{ODP}=0)$ and local fabrication.

Beside certified SNI / ISO / ecolab, for other material specifications refers to requirements that prioritize the expenditure of environmentally friendly materials such as regional production, recyclable materials, reused materials, renewable materials and other eco-categorized environmental friendly materials.

4. To answer RQ.4 Establish implementation guidelines for maintenance, reparation and specification of materials for mechanical component design in government own green buildings based on work breakdown structure. Table 4 shows the implementation guidelines that provide detailed information about WBS levels, alternative designs/ methods, activities, implementation requirements, resources and material specifications required to complete mechanical work in government own green buildings.

Table 4. Implementation guidelines for air cooled chiller

\begin{tabular}{|c|c|c|c|}
\hline \multicolumn{4}{|c|}{ CHILLER } \\
\hline \multicolumn{4}{|c|}{$\begin{array}{l}\text { Description : } \\
\text { Chiller work package includes the provision of manpower, materials, } \\
\text { equipment and tools needed for the work perform }\end{array}$} \\
\hline \multicolumn{4}{|c|}{ AIR COOLED CHILLER } \\
\hline WBS Code & \multicolumn{3}{|c|}{ Description } \\
\hline WBS Level 2 & & Mechanical \\
\hline WBS Level 3 & \multicolumn{2}{|c|}{ Sub Work Section } & Air System \\
\hline WBS Level 4 & \multicolumn{2}{|c|}{ Work Package } & Chiller \\
\hline & \multicolumn{2}{|c|}{ Alternative Design/ Method } & Air Cooled Chiller \\
\hline $\begin{array}{c}\text { WBS Level } 5 \\
\text { (Activity) }\end{array}$ & \multicolumn{2}{|c|}{$\begin{array}{l}\text { WBS Level } 6 \\
\text { (Resources) }\end{array}$} & $\begin{array}{c}\text { Specification } \\
\text { Material }\end{array}$ \\
\hline Inspection & $\begin{array}{l}\text { Manpower: } \\
\text { Equipment : }\end{array}$ & $\begin{array}{l}\text { Mechanical } \\
\text { Technician } \\
\text { Checklist, } \\
\text { pressure } \\
\text { gauge }\end{array}$ & $\begin{array}{l}\text { Refer to Standar } \\
\text { Nasional } \\
\text { Indonesia (SNI) } \\
6390: 2011 \text { [8]. }\end{array}$ \\
\hline Maintenance & $\begin{array}{l}\text { Manpower: } \\
\text { Equipment : } \\
\text { Material : }\end{array}$ & $\begin{array}{l}\text { Mechanical } \\
\text { Technician } \\
\text { Plastic/brass } \\
\text { brush, water } \\
\text { pump, wipes } \\
\text { Chemical } \\
\text { liquid, } \\
\text { refrigerant, oil }\end{array}$ & $\begin{array}{l}\text { Certified by ISO } \\
14001 \text { about } \\
\text { environmental } \\
\text { management } \\
\text { system. } \\
\text { Certified by ISO } \\
9001 \text { about quality }\end{array}$ \\
\hline Reparation & $\begin{array}{l}\text { Manpower: } \\
\text { Equipment : } \\
\text { Material : }\end{array}$ & $\begin{array}{l}\text { Mechanical } \\
\text { Technician } \\
\text { Chiller set } \\
\text { repair } \\
\text { equipment } \\
\text { Filters, } \\
\text { compressors, } \\
\text { condensers, } \\
\text { metering } \\
\text { devices, } \\
\text { evaporators }\end{array}$ & $\begin{array}{l}\text { management } \\
\text { system } \\
\text { Use non-CFC/ } \\
\text { non-HCFC } \\
\text { refrigerant } \\
(\mathrm{ODP}=0) \text {. } \\
\text { Regional } \\
\text { Production. }\end{array}$ \\
\hline Testing & $\begin{array}{l}\text { Manpower : } \\
\text { Equipment : }\end{array}$ & $\begin{array}{l}\text { Mechanical } \\
\text { Technician } \\
\text { Chiller set } \\
\text { testing } \\
\text { equipment }\end{array}$ & \\
\hline \multicolumn{4}{|c|}{ Implementation Requirement : } \\
\hline \multicolumn{4}{|c|}{$\begin{array}{l}\text { Inspection : } \\
\text {-Chiller check periodically. } \\
\text {-Compression check of the compressor that measured at the high } \\
\text { pressure side (discharge) and the low pressure side (suction). } \\
\text { - By using pressure gauge, oil pressure as the lubricat parts moving in } \\
\text { the compressor are measured periodically. While lhe level of oil that } \\
\text { can be seen in sigh glass visually should be considered and should not } \\
\text { bel lower than factory required. } \\
\text {-Check the refrigerant pressure on the condenser and cooler on a } \\
\text { regular basis to determine whether heat transfer is good or not. } \\
\text {-Check the fan motor that serves to move the cooling air (especially } \\
\text { for condenser). } \\
\text { - routine checking of metering device. } \\
\text { - inspection of water inlet and outlet against leakage. } \\
\text {-Colling coil check against leakage and corrosion. } \\
\text {-Check operation of the actuator control zone. } \\
\text {-Inspection of the water damper operation. } \\
\text {-Inspection of fresh air damper operation. } \\
\text {-filter check. } \\
\text {-inspection of refrigerant, to use non-CFC refrigerant. } \\
\text { analyze whether chiller maintenance/ reparation is necessary. }\end{array}$} \\
\hline \multicolumn{4}{|c|}{$\begin{array}{l}\text { Maintenance : } \\
\text { - Prepare the equipment and mateials needed for chiller maintenance. } \\
\text { - Reset the metering device when the refrigerant flow is interrupted. } \\
\text { - Clean the dirt on the compressor valve and reset. } \\
\text { - add compressor oil periodically } \\
\text { - The condenser machine needs to be cleaned regularly on the cooling } \\
\text { fluid side. The air-cooled condenser requires cleaning of the fins on } \\
\text { the air side. } \\
\text { - For air-cooled condensers, external airflow needs to be maintained }\end{array}$} \\
\hline
\end{tabular}




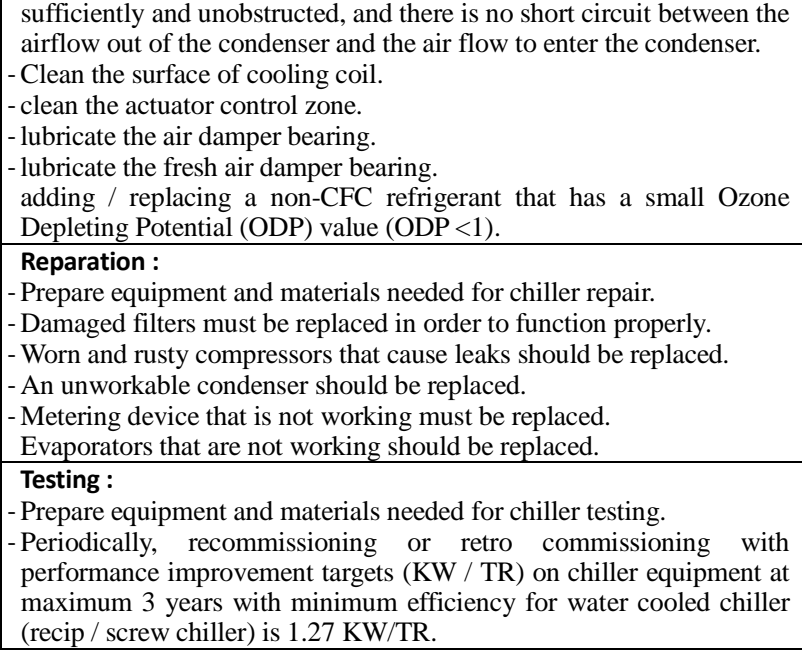

Prepare equipment and materials needed for chiller repair.

Damaged filters must be replaced in order to function properly.

Worn and rusty compressors that cause leaks should be replaced.

An unworkable condenser should be replaced.

Metering device that is not working must be replaced.

Evaporators that are not working should be replaced.

Testing :

- Prepare equipment and materials needed for chiller testing.

- Periodically, recommissioning or retro commissioning with performance improvement targets (KW / TR) on chiller equipment at maximum 3 years with minimum efficiency for water cooled chiller (recip / screw chiller) is $1.27 \mathrm{KW} / \mathrm{TR}$.

\section{Conclusion}

The implementation guideline is the required reference in every work. Development of Implementatiion Guidelines for maintenance and reparation work for mechanical components in government own green building based on work breakdown structure facilitate the users in implementing the work and the determination of material specifications for the design make the material stock more effective.

\section{References}

1. Bon-Gang Hwang, Xianbo Zhao, Lene Lay Ghim Tan, (2015) "Green building projects: schedule performance, influential factors and solutions", Engineering, Construction and Architectural Management, Vol. 22 Issue: 3, pp.327-346.

2. Hwang Bon-Gang, Jack See Tan, "Sustainable Project Management for Green Construction :
Challenges, Impact and Solutions", World Construction Conference, Sri Lanka, June 2012.

3. A Guide to The Project Management Body of Knowledge PMBOK GUIDE Sixth Edition.

4. Peraturan Presiden Republik Indonesia Nomor 73 Tahun 2011, "Pembangunan Bangunan Gedung Negara".

5. A Guide to The Project Management Body of Knowledge PMBOK GUIDE Sixth Edition.

6. Peraturan menteri Pekerjaan Umum Nomor 24/PRT/M/2008, "Pedoman Pemeliharaan dan Perawatan Bangunan Gedung”.

7. Standar Nasional Indonesia (SNI) 6390:2011, "Konservasi Energi Sistem Tata Udara Bangunan Gedung".

8. Rajasa Miralia. Pengembangan Standar WBS (Work Breakdown Strukture) Untuk Estimasi Biaya Pekerjaan Mekanikal dan Elektrikal Bangunaan Gedung Berbasis Risiko. Fakultas Teknik Universitas Indonesia. 2017.

9. Peraturan Gubernur Provinsi Daerah Khusu Ibukota Jakarta Nomor 38 Tahun 2012, "Bangunan Gedung Hijau"

10. Sana Azeem, Malik Asghar Naeem, Abdul Waheed, Muhammad Jamaluddin Thaheem, (2017) "Examining barriers and measures to promote the adoption of green building practices in Pakistan", Smart and Sustainable Built Environment, Vol. 6 Issue: 3 , pp.86-100.

11. Suzaini M. Zaid, Amir Kiani Rad, Nurshuhada Zainon, (2017) "Are green offices better than conventional?: Measuring operational energy consumption and carbon impact of green office in Malaysia", Facilities, Vol. 35 Issue: 11/12, pp.622637. 